\title{
Migration of Bovine Aortic Smooth Muscle Cells after Wounding Injury The Role of Hyaluronan and RHAMM
}

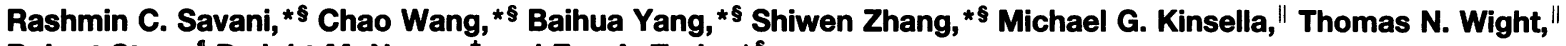 \\ Robert Stern, ${ }^{\top}$ Dwight M. Nance, ${ }^{\ddagger}$ and Eva A. Turley*\$ \\ ${ }^{*}$ Departments of Pediatrics, ${ }^{\ddagger}$ Pathology and ${ }^{\S}$ The Manitoba Institute of Cell Biology, University of Manitoba, Winnipeg, Manitoba, \\ Canada; "Department of Pathology, University of Washington, Seattle, Washington; and "Department of Pathology, University \\ of California San Francisco, San Francisco, California
}

\begin{abstract}
The migration of smooth muscle cells is a critical event in the pathogenesis of vascular diseases. We have investigated the role of hyaluronan (HA) and the hyaluronan receptor RHAMM in the migration of adult bovine aortic smooth muscle cells (BASMC). Cultured BASMC migrated from the leading edge of a single scratch wound with increased velocity between 1 and $24 \mathrm{~h}$. Polyclonal anti-RHAMM antisera that block HA binding with this receptor abolished smooth muscle cell migration following injury. HA stimulated the random locomotion of BASMC and its association with the cell monolayer increased following wounding injury. Immunoblot analysis of wounded monolayers demonstrated a novel RHAMM protein isoform that appeared within one hour after injury. At the time of increased cell motility after wounding, FACS ${ }^{\circledR}$ analysis demonstrated an increase in the membrane localization in $\sim 25 \%$ of the cell population. Confocal microscopy of injured monolayers confirmed that membrane expression of this receptor was limited to cells at the wound edge. Collectively, these data demonstrate that RHAMM is necessary for the migration of smooth muscle cells and that expression and distribution of this receptor is tightly regulated following wounding of BASMC monolayers. (J. Clin. Invest. 1995. 95:1158-1168.) Key words: smooth muscle cells $\bullet$ wound injury $\bullet$ migration - hyaluronan - receptor
\end{abstract}

\section{Introduction}

Smooth muscle cell migration is a critical component in many pathologic vascular processes including atherosclerosis (1), restenosis after balloon angioplasty (2), and hypertension (3). These processes involve a response to injury that results in the production of growth factors, which then activate locomotion of the cells (4). Very little is known about the mechanisms mediating injury-induced locomotion. However, components of the extracellular matrix, the production of which are regulated

Address correspondence to Eva A. Turley, ON 220, 100 Olivia St., Winnipeg, Manitoba, R3E 0V9, Canada. Phone: (204) 787-2137; FAX: (204) 787-2190.

Received for publication 7 September 1993 and in revised form 20 September 1994.

J. Clin. Invest.

(C) The American Society for Clinical Investigation, Inc.

0021-9738/95/03/1158/11 \$2.00

Volume 95, March 1995, 1158-1168 by growth factors, have been implicated in the process (5). For example, Naito et al. (6) have shown that fibrinogen and fibrin stimulate the chemotaxis of cultured smooth muscle cells, while heparin and heparin-like glycosaminoglycans inhibit their migration in a dose-dependent and reversible manner (7).

Hyaluronan (HA ), ${ }^{1}$ a component of the extracellular matrix, has been implicated in cell locomotion during embryogenesis $(8,9)$, tumor invasion $(10)$, transformation by oncogenes $(11)$, and in responses to injury (12-14). HA has also been shown to stimulate the migration of endothelial cells. Thus, the leading edges of newly-sprouting capillaries are enriched with HA (15), and 3-16 oligomers of HA have been shown to be angiogenic $(16,17)$. Furthermore, Banerjee and Toole (18) have reported that an endothelial cell surface HA-binding protein is involved in endothelial cell migration and tubule formation in vitro. The nature of this protein, however, is unknown.

The role of HA in adult smooth muscle cell migration has not been well studied, although HA has been implicated in the migration of embryonic smooth muscle cells in the ductus arteriosus of fetal lambs (19). Majack and Clowes (7) examined the effect of HA on adult smooth muscle cells, but showed only a small increase in their migration. However, the dose of $100 \mu \mathrm{g} / \mathrm{ml}$ of HA used in their study is at least 1000 -fold higher than the dose $(100 \mathrm{pg} / \mathrm{mL})$ required to maximally stimulate locomotion of ras-transformed fibroblasts (11), and may not have been optimal.

The effect of HA on cell locomotion appears to be mediated by specific receptors $(20,21)$. Two of these receptors have been molecularly characterized and include CD44 (22) and receptor for HA-mediated motility (RHAMM) (23). We have isolated (24), characterized (25), and cloned (23) the HA receptor RHAMM. This protein has been shown to be critical to the invasion of smooth muscle cells isolated from the ductus arteriosus of fetal lambs into three-dimensional collagen gels (26), to HA stimulation of ras-transformed fibroblast locomotion (11), and to TGF- $\beta_{1}-$ stimulated locomotion of fibroblasts (27). We report here the involvement of RHAMM during the migration of adult bovine aortic smooth muscle cells following in vitro wounding.

\section{Methods}

Tissue culture. Smooth muscle cells were isolated from bovine aorta as described previously for rat aorta (7). Briefly, the endothelial layer was

1. Abbreviations used in this paper: BASMC, bovine aortic smooth muscle cells; BHA, biotinylated HA; DM, defined medium; FP, fusion protein; GST, slutathione-s-transferase; HA, hyaluronan (hylanuronate, hyaluronic acid); HABP, HA-binding region of aggrecan; RHAMM, receptor for HA-mediated motility; RT-PCR, reverse transcriptase polymerase chain reaction. 
stripped using sterile forceps. Strips of the exposed medial layer of the vessel were then cut into $1-\mathrm{mm}^{3}$ pieces and cultured in DME (GIBCO BRL Inc., Burlington, Ontario) in the presence of $10 \%$ Hyclone FCS (GIBCO BRL), $20 \mathrm{mM}$ Hepes buffer, pH 7.2 (Sigma Chemical Co., St. Louis, MO), and $1 \%$ Penicillin/Streptomycin mixture (GIBCO BRL). Smooth muscle cells that migrated out of the explants were subcultured and maintained in DME supplemented with $10 \%$ FCS and $20 \mathrm{mM}$ Hepes

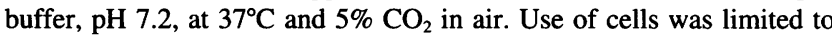
low passage number $(3-10)$. The cells were grown to confluence in monolayers in 100 - or $150-\mathrm{mm}^{2}$ tissue culture plates, or in $25-\mathrm{cm}^{2}$ tissue culture flasks before wounding. All experiments were performed using defined medium (DM: DME with $20 \mathrm{mM}$ Hepes buffer, $\mathrm{pH}$ 7.2, $0.5 \mathrm{U} /$ $\mathrm{ml}$ insulin [beef and pork zinc suspension; Novo Laboratories Ltd., Willowdale, Ontario] and $4 \mu \mathrm{g} / \mathrm{ml}$ transferrin [Sigma]), and the culture medium was replaced $24 \mathrm{~h}$ before filming or extraction.

Wounding injury to the monolayers consisted of removal of half the monolayer using a cell lifter (Costar, Cambridge, MA) followed by the addition of fresh DM. Control monolayers received fresh medium without injury.

Time-lapse cinemicrography. Injured cell monolayers were monitored for motility using an IM 35 inverted microscope (Zeiss, Oberkochen, Germany) to which a video camera (Hamamatsu CCD, Inc., Hamamastu City, Japan) was attached. The cells were maintained at $37^{\circ} \mathrm{C}$ using a heated platform (TRZ 3700; Zeiss). Cell locomotion was followed by using image analysis (Image 1; Universal Imaging Corp., Westchester, PA). This program allows quantification of nuclear displacement in a sequence of digitalized images. The motility of thirty cells in each experiment was followed for a period of $24 \mathrm{~h}$ with mean velocities calculated every hour.

In experiments that studied the effect of exogenous HA on the random locomotion of smooth muscle cells, subconfluent monolayers were examined with time-lapse cinemicrography. Cells maintained in DM in the absence of HA initially were filmed for $4 \mathrm{~h}$. Since $\mathrm{HA}$ at a concentration of $0.01 \mu \mathrm{g} / \mathrm{ml}$ had been shown to maximally stimulate ras-transformed fibroblast locomotion (10), this amount of HA (Sigma) was added to the medium and cells were monitored for a further 4-h period. The mean velocity of 30 cells was calculated for each 4-h period examined.

Antisera. A polyclonal antiserum was raised in rabbits to a specific peptide ( $\mathrm{aa}^{268-288}$ ) encoded in the RHAMM cDNA (23) that was determined to be antigenic by analysis of its hydrophobicity profile. The specificity of the antiserum (anti-peptide ${ }^{\mathrm{a} 268-288} \mathrm{Ab}$ ) for this epitope was confirmed using truncated forms of the RHAMM cDNA that were expressed in the bacterial expression vector pGEX-2T and immunoblot assays of the resulting glutathione-s-transferase (GST)-fusion proteins. The specificity of the antiserum was further demonstrated by the ability of preincubation with the GST-RHAMM fusion protein to block subsequent staining for RHAMM in SDS-PAGE immunoblots (see Fig. 1).

As an additional antibody to be used for confirmation of the properties of anti-peptide ${ }^{\text {aa268-288 }} \mathrm{Ab}$, complete GST-RHAMM fusion protein, prepared as described by Yang et al. (28), was used to immunize rabbits and the polyclonal antiserum produced (anti-FP $\mathrm{Ab}$ ) was also used in the locomotion inhibition assays described above.

To investigate whether these antisera prevented HA-binding to RHAMM, the GST-RHAMM fusion protein was separated in an SDSPAGE transblot. The blot was incubated with either anti-peptide ${ }^{\text {aa268- }}$ ${ }^{288} \mathrm{Ab}$ or anti-FP $\mathrm{Ab}$ overnight at $4^{\circ} \mathrm{C}$ and then further probed with biotinylated HA as described previously (29). Streptavidin conjugated with horse radish peroxidase was used to identify bound biotinylated HA. The control fusion protein lane was probed with biotinylated HA without prior incubation with the antisera.

The identity of the cultured cells as smooth muscle was confirmed using a monoclonal antibody to smooth muscle cell-specific alpha-actin ( $2 \mu \mathrm{g} / \mathrm{ml}$; Sigma) in immunoblot analyses performed in the manner described below. A protein band of $42 \mathrm{kD}$, the expected size for smooth muscle cell alpha-actin, was seen (see Fig. $1 d$ ).

Measurement and detection of hyaluronan association with the cell monolayer. To quantify the HA associated with the monolayers, the HA-binding region of aggrecan (HABP) was isolated, purified and biotinylated from bovine nasal cartilage as described previously (30). Smooth muscle cell monolayers before and at 1, 3, 6, 12, and $18 \mathrm{~h}$ after injury were fixed in $3 \%$ paraformaldehyde and then incubated with a 1:300 dilution of biotinylated HABP. The cells were then incubated with horse radish peroxidase-conjugated avidin and staining was achieved using diaminobenzidine as substrate. The staining was semiquantitatively scored by a blinded observer on a scale of 0 to 4 , from no staining to maximum staining.

Immunofluorescence. Monolayers were fixed in 3\% paraformaldehyde in PBS, pH 7.4, for $10 \mathrm{~min}$ and then washed with PBS. Autofluorescence was quenched by treating the cells with $1 \mathrm{M}$ glycine in PBS for $1 \mathrm{~h}$ at room temperature. The cells were then incubated overnight at $4^{\circ} \mathrm{C}$ with primary antiserum (anti-peptide ${ }^{\text {aa268-288 }} \mathrm{Ab}, 1: 50$ dilution), or in control conditions ( $200 \mu \mathrm{g} / \mathrm{ml} \mathrm{Rabbit} \mathrm{IgG} \mathrm{previously} \mathrm{adsorbed} \mathrm{to}$ bovine white blood cells) in PBS with $10 \%$ FCS and $0.02 \%$ sodium azide. The cells were incubated with a 1:300 dilution of rhodamineconjugated goat anti-rabbit immunoglobulin G (Sigma) for 2-3 h at room temperature in the dark. Cells were mounted in Permount ${ }^{\circledR}$ (Fisher Scientific, Pittsburgh, PA) and immunofluorescence was viewed with epifluorescence at $510-560 \mathrm{~nm}$.

Live cell-immunofluorescence was performed in a similar manner except that cells were incubated with the primary antiserum diluted in DM for $30 \mathrm{~min}$, washed twice with PBS, incubated with secondary antiserum (also in DM) for a further $30 \mathrm{~min}$ and then fixed with fresh $3 \%$ paraformaldehyde.

Confocal images. Monolayers, prepared in a similar manner to that described for immunofluorescence, were studied by confocal microscopy to analyze membrane association of the receptor. The secondary antibody used in these studies was a phycoerythrin-conjugated goat anti-rabbit antibody (1:300 dilution; Sigma). The confocal scanning laser microscope (CSLM) images were generated on a Molecular Dynamics CSLM equipped with an argon laser and a Nikon $60 \times$ oil immersion ( 1.4 n.a.) objective. The 514-nm laser line was used for excitation of phycoerythrin in conjunction with a $525-\mathrm{nm}$ beam splitter and a 535$\mathrm{nm}$ long-pass filter. Individual optical sections were $512 \times 512$ pixels $(0.17 \mu \mathrm{m} / \mathrm{pixel})$ and separated by $0.49-\mu \mathrm{m}$ steps. The final images were volume rendered on a Silicon Graphics Indigo computer utilizing ImageSpace software interpolation. The digital images were subsequently photographed with a digitalized film recorder (Lasergraphics, Irvine, CA) onto Kodak Ectachrome film.

Flow cytometry. Smooth muscle cells were harvested before injury and at $1,3,6,12$, and $18 \mathrm{~h}$ after injury using PBS with $2.5 \%$ bovine serum albumin and $2.5 \mathrm{mM}$ EDTA for $2 \mathrm{~min}$. The cells were washed in PBS with $2.5 \%$ bovine serum albumin, incubated with anti-peptide ${ }^{\text {aa268-288 }} \mathrm{Ab}$ ( 1:50 dilution) for $30 \mathrm{~min}$ at room temperature, washed again and then incubated with fluorescein-conjugated goat anti-rabbit antiserum (1:300 dilution) for a further $30 \mathrm{~min}$ before fixing with $3 \%$ paraformaldehyde. The surface expression of RHAMM was studied using immunofluorescence flow cytometry. Rabbit IgG was used as a control at each timepoint analyzed.

The FACS ${ }^{\circledR}$ data were further analyzed by calculating the fold change (from uninjured monolayer values) of the percentage of the cell population expressing fluorescent intensities greater than the 25th percentile, in order to obtain the proportion of cells increasing the surface expression of RHAMM after injury.

Immunoblot analysis. Smooth muscle cell monolayers were lysed at $4^{\circ} \mathrm{C}$ using lysis buffer $(25 \mathrm{mM}$ Tris $-\mathrm{HCl}, 0.1 \%$ sodium dodecyl sulfate, $1 \%$ Triton $\mathrm{X}-100,1 \%$ sodium deoxycholate, $0.15 \mathrm{M} \mathrm{NaCl}, 1 \mathrm{mM}$ EDTA, and the protease inhibitors leupeptin $[1 \mu \mathrm{g} / \mathrm{ml}]$, phenylmethyl sulfonylfluoride [ $2 \mathrm{mM}$ ], pepstatin A [ $1 \mu \mathrm{g} / \mathrm{ml}]$, aprotinin [ 0.2 international units of activity $\{\mathrm{TIU}\} / \mathrm{mL}$ ], and 3,4-dichloroisocoumarin [200 $\mu \mathrm{M}]$ ). Protein concentration was determined by the DC protein assay method (Bio-Rad Labs., Richmond, CA) using an equal sample of the lysis buffer for background determination. $5 \mu \mathrm{g}$ of protein from each sample were separated on $10 \%$ SDS-PAGE and transblotted onto nitro- 
cellulose membranes. Additional protein binding sites on the membrane were blocked with $5 \%$ defatted milk in TTBS $(0.01 \mathrm{M}$ Tris base, 150 $\mathrm{mM} \mathrm{NaCl}, \mathrm{pH} 7.4$, with $0.05 \%$ Tween 20 [Sigma]). Blots were incubated with the primary antiserum (anti-peptide ${ }^{\text {aa268-288 }} \mathrm{Ab}, 1: 300$ dilution in $1 \%$ defatted milk in TTBS) overnight at $4^{\circ} \mathrm{C}$. The primary antiserum was detected using goat anti-rabbit IgG antibody conjugated to horse radish peroxidase $(0.2 \mu \mathrm{g} / \mathrm{ml}$ in $1 \%$ defatted milk in TTBS; Sigma), incubated for $1 \mathrm{~h}$ at room temperature and was visualized with ECL (Amersham Corp., Arlington Heights, IL) as per manufacturer's instructions.

Northern blot analysis. Total cell RNA was extracted using the method described by Chomczynski and Sacchi (31). Briefly, the cells were initially denatured in Solution D ( $4 \mathrm{M}$ guanidinium thiocyanate, $25 \mathrm{mM}$ sodium citrate, $\mathrm{pH} 7,0.5 \%$ sarcosyl, $0.1 \mathrm{M}$ 2-mercaptoethanol). RNA was extracted with phenol-chloroform-isoamyl alcohol in the presence of $3 \mathrm{M}$ sodium acetate. The RNA in the aqueous phase was precipitated twice with $100 \%$ ethanol at $-20^{\circ} \mathrm{C}$ and pelleted by centrifugation. The final pellet was dissolved in diethyl pyrocarbonate-treated water. Purity and quantity of the RNA was assessed by reading optical densities at 260 and $280 \mathrm{~nm}$. Total cell RNA ( $80 \mu \mathrm{g})$ was separated using gel electrophoresis in $1 \%$ agarose gels and transferred to Nytran " paper (Schleicher \& Schuell, Keene, NH) under capillary transfer. The blots were baked in a vacuum oven at $80^{\circ} \mathrm{C}$ for $2 \mathrm{~h}$ and then incubated in prehybridization buffer $(50 \%$ formamide, $6 \times$ SSPE, $5 \times$ Denhardt's solution, $0.1 \%$ SDS, and $100 \mu \mathrm{g} / \mathrm{ml}$ denatured salmon sperm DNA) for a minimum of $3 \mathrm{~h}$ at $42^{\circ} \mathrm{C} .{ }^{32} \mathrm{P}$-labeled cDNA for RHAMM was used to hybridize to the immobilized RNA species in hybridization buffer ( $50 \%$ formamide, $6 \times$ SSPE, $5 \times$ Denhardt's solution, $0.1 \%$ SDS, $10 \%$ dextran sulfate, $100 \mu \mathrm{g} / \mathrm{ml}$ denatured salmon sperm DNA, and $2 \times 10^{6}$ cps of radioactive probe per $\mathrm{ml}$ of hybridization solution) overnight at $42^{\circ} \mathrm{C}$. The blots were then washed with increasing stringency twice in $2 \times \mathrm{SSC}, 0.1 \% \mathrm{SDS}$ for $30 \mathrm{~min}$ at room temperature, and once in $0.4 \times$ SSC, $0.1 \%$ SDS for $10 \mathrm{~min}$ at $68^{\circ} \mathrm{C}$ to remove nonspecifically bound probe. An autoradiograph was obtained by exposing the blot to Kodak XOMAT XAR-5 film. The size of transcript identified by hybridization was calculated using an external RNA ladder $(0.24-9.5 \mathrm{~kb}$; GIBCO BRL).

Reverse transcriptase polymerase chain reaction (RT-PCR). The changes in RHAMM mRNA content after wounding were studied using quantitative RT-PCR. Reverse transcription was performed using reverse transcriptase and the First-Strand cDNA Synthesis Kit (Clontech Laboratories, Inc., San Francisco, CA) according to manufacturer's instructions. Briefly, $1 \mu \mathrm{g}$ total RNA, extracted as described above, was reverse transcribed using a 16-mer oligo dT primer and $100 \mathrm{U}$ MMLV reverse transcriptase at $42^{\circ} \mathrm{C}$ for $60 \mathrm{~min}$. The total $20-\mu \mathrm{l}$ reaction was heated to $95^{\circ} \mathrm{C}$ for $5 \mathrm{~min}$ and the resulting cDNA solution was diluted to $100 \mu \mathrm{l}$ by adding $80 \mu \mathrm{l}$ of sterile water. $5 \mu \mathrm{l}$ of the diluted cDNA was used in each 50- $\mu$ l PCR reaction using primers derived from the published murine RHAMM cDNA (23) that resulted in a product encoded by RHAMM nucleotides 1-762. The primers used were as follows: sense strand: 5'-ATGCAGATCCTGACAGAGAGG-3', and complimentary strand: 5'-AGCCATAGCTACTTTTTCTTG-3'. Control primers for human $\beta$-actin, supplied with the kit and known to be homologous to that of bovine $\beta$-actin, were used as an internal control to assure equal loading and amplification of all samples. The PCR reaction was performed in the order of $94^{\circ} \mathrm{C}(1 \mathrm{~min}), 55^{\circ} \mathrm{C}(45 \mathrm{~s})$, $72^{\circ} \mathrm{C}$ ( $1.5 \mathrm{~min}$ ) for 30 cycles. The PCR products were electrophoresed on a $1.2 \%$ agarose gel and stained with ethidium bromide.

\section{Results}

Characterization of anti-RHAMM antisera. The specificity of anti-peptide ${ }^{\text {a2268-288 }} \mathrm{Ab}$ was confirmed using immunoblot analysis of increasingly truncated fusion proteins expressed in a bacterial expression vector (28). The antiserum only reacted with fusion protein fragments that contained the peptide to which

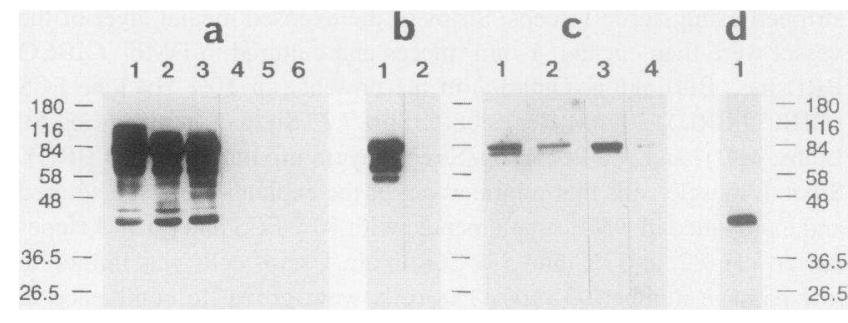

Figure 1. Characterization of anti-RHAMM antisera. Polyclonal antiserum to a specific peptide ( $a^{268-288}$ ) encoded in the RHAMM cDNA was raised in rabbits. ( $a$ ) The specificity of the antiserum was confirmed using immunoblot assays of fusion proteins generated by expression of truncated forms of the RHAMM CDNA in a bacterial expression vector. The antiserum only reacted with the fusion proteins containing the sequence with which the antiserum was raised (aa 268 to 288). Lane 1 represents the whole GST-RHAMM fusion protein (aa 1-476), lanes $2-5$ represent truncations of the protein at aa $1-435,1-339,1-238$, and $1-136$, respectively, and lane 6 represents a bacterial lysate without the RHAMM insert. ( $b$ ) Preincubation of the antiserum with the complete GST-RHAMM fusion protein prevented staining in the immunoblot assay further confirming the specificity of the antiserum. Lane $I$ shows antiserum recognizing electrophoresed fusion protein while lane 2 shows blocking of staining when the antiserum was preincubated with RHAMM fusion protein. (c) To study the effect of anti-RHAMM antisera on the RHAMM/HA interaction, binding of biotinylated HA (BHA) to the complete fusion protein was analyzed in a transblot assay. Lanes 1 and 3 represent control lanes where BHA was used to stain GST-RHAMM fusion protein. Prior incubation of the fusion protein with anti-RHAMM peptide ${ }^{\mathrm{aa268-288}} \mathrm{Ab}$ decreases the binding of BHA to $40 \%$ that of control (lane 2), while anti-Fusion Protein $\mathrm{Ab}$ resulted in a $95 \%$ inhibition of HA binding to RHAMM (lane 4). (d) The identity of the monolayers as smooth muscle cell in origin was confirmed by positive reaction to anti-smooth muscle-specific actin $\mathrm{Ab}$ (molecular mass $42 \mathrm{kD}$ ). Protein standards used for molecular mass determination: $180,116,84,58,48,36.5$, and $26.5 \mathrm{kD}$.

the antiserum was raised (Fig. $1 \mathrm{a}$ ). The specificity of the antiserum was further demonstrated by the ability of soluble GST-RHAMM fusion protein (FP, reference 28 ) to block antiserum-RHAMM interaction on transblots (Fig. $1 b$ ). The antiserum reduced the binding of biotinylated HA to GST-RHAMM fusion protein by $60 \%$ in a transblot assay (Fig. $1 \mathrm{c}$ ). The ability of anti-FP Ab to prevent RHAMM/HA interaction was also tested using this method, and this antiserum reduced biotinylated HA binding to RHAMM by $95 \%$ (Fig. $1 c$ ).

RHAMM regulation of smooth muscle cell migration into wounds. Smooth muscle cells migrated into the wound in a highly directional manner (Fig. 2). The velocity of migrating cells was significantly increased (fourfold from baseline, $P$ $<0.01$, Student's $t$-test) by $1 \mathrm{~h}$ after injury, with a further increase (fivefold) between 4 and 8 h (Fig. 3). Two large (eightfold) increases in velocity were also seen between 8 and $15 \mathrm{~h}$ after wounding ( $P<0.001$, Student's $t$-test, Fig. 3 ). The velocity of the cells had declined by $18 \mathrm{~h}$, although cells continued to migrate into the wound. Anti-peptide ${ }^{a 268-288} \mathrm{Ab}$ (1:300 dilution) inhibited the emigration of the cells from the wound (Figs. 2 and 3). The inhibitory effect of the antiserum lasted $20 \mathrm{~h}$, after which the cells began migrating into the wound at rates observed for untreated cells at the same time after injury (Fig. 3). Similar results for the inhibition of cell migration were obtained using anti-FP Ab (1:300 dilution, Table I), an 


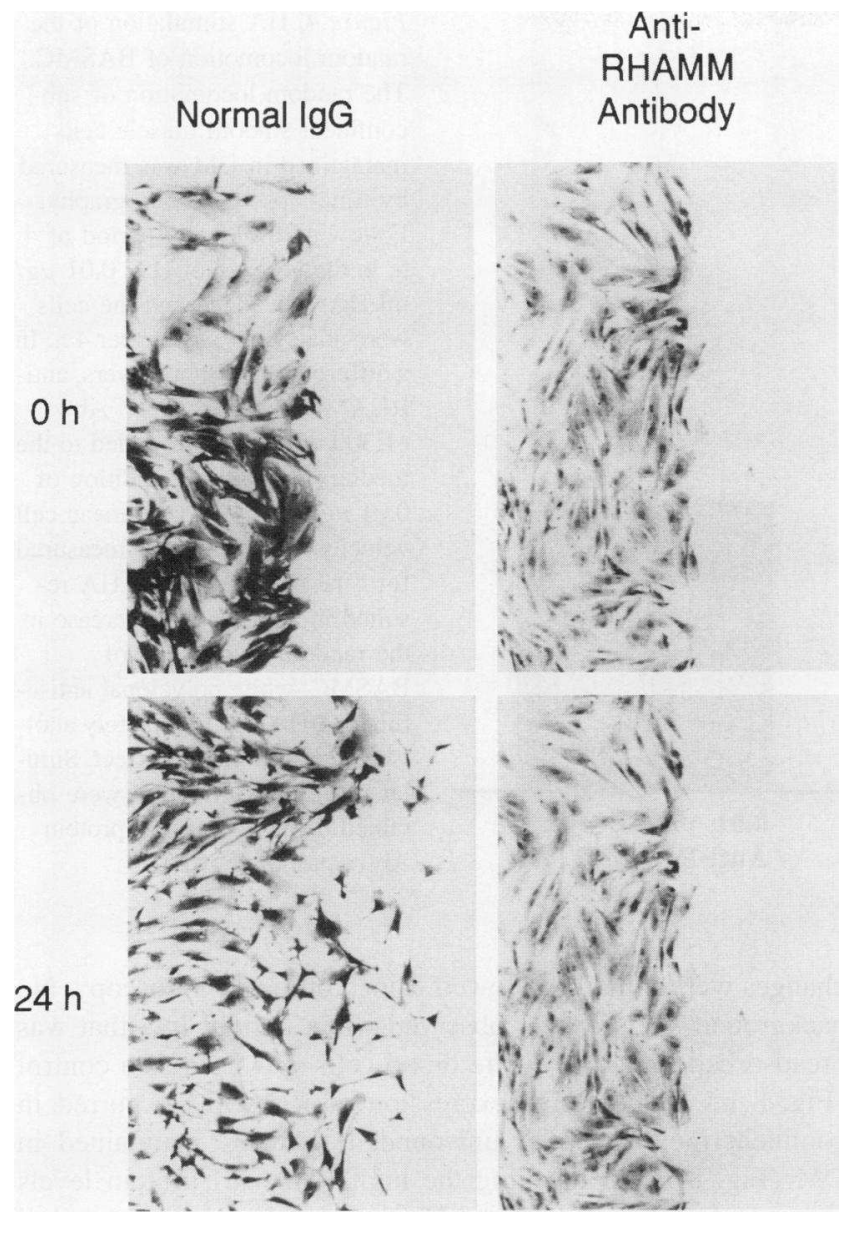

Figure 2. The directional migration of BASMC monolayers following wounding. In vitro cultures of BASMC were wounded by removal of half the monolayer. Cells were noted to move into the wounded area in a highly directional manner over $24 \mathrm{~h}$ in the presence of normal rabbit IgG. However, in the presence of anti-RHAMM peptide ${ }^{\text {a2268-288 }}$ $\mathrm{Ab}$, this migration was completely inhibited. Similar results were obtained for anti-Fusion Protein Ab (data not shown). Monolayers were stained with LeukoStat ${ }^{\text {TM }}$ (Fisher Scientific) for photography.

antiserum that efficiently blocks the interaction between RHAMM and HA (Fig. $1 c$ ).

Hyaluronan regulates random smooth muscle cell locomotion and its association with the monolayer increases following injury. To assess the role of HA and the RHAMM-HA interaction in smooth muscle cell motility, the random locomotion of sub-confluent bovine aortic smooth muscle cells was measured with time-lapse cinemicrography in DM. Addition of $0.01 \mu \mathrm{g} /$ $\mathrm{ml}$ HA caused a significant increase in the random locomotion of these cells (Fig. 4). Both anti-peptide ${ }^{\text {aa268-288 }} \mathrm{Ab}$ and antiFP Ab (1:300 dilutions) abolished this HA-mediated increase in random locomotion (Fig. 4).

In separate experiments, injured and intact smooth muscle cell monolayers were probed with biotinylated HABP, the HAbinding region of aggrecan isolated from bovine nasal cartilage (30), as a method for detecting cell-associated HA. HA increased maximally by $3 \mathrm{~h}$ after injury and disappeared by $18 \mathrm{~h}$ (Fig. $5 a$ ). Further, the major increase in HA at $3 \mathrm{~h}$ was localized primarily at the wound edge (Fig. $5 \mathrm{~b}$, arrows). This
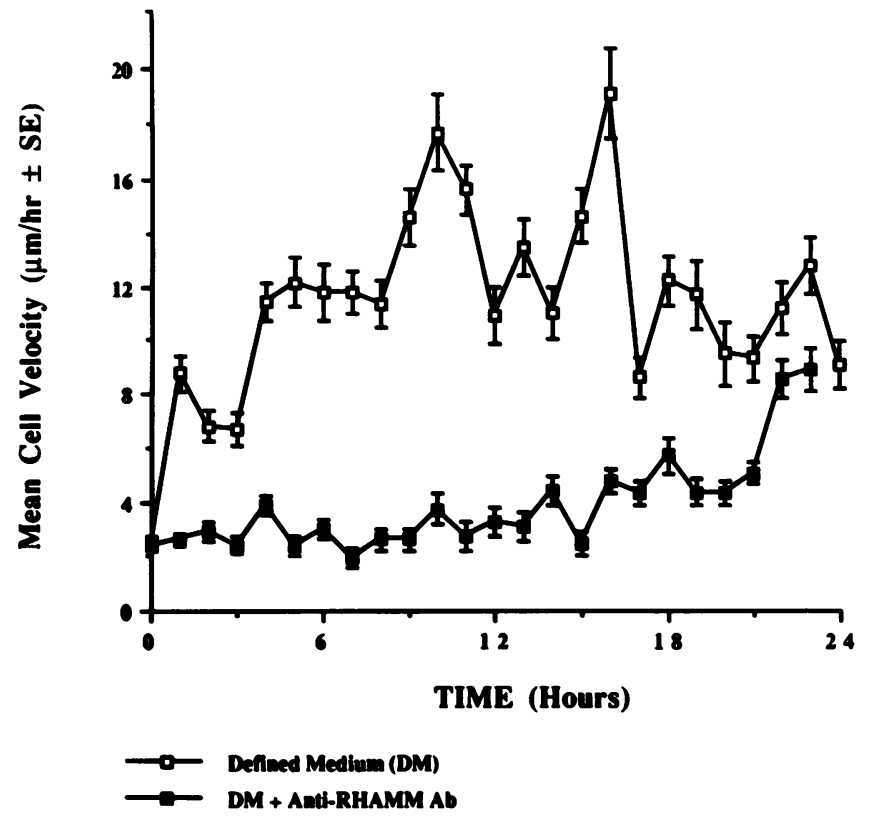

Figure 3. Mean hourly velocities of wounded BASMC monolayers maintained in defined medium and the effect of anti-RHAMM peptide ${ }^{\text {aa268-288 }} \mathrm{Ab}$. Using time-lapse cinemicrography, increased cell velocity after wounding was evident by one hour after injury with a further increase between 4 and $8 \mathrm{~h}$ (Students $t$-test, $P<0.01$ ). Two major increases in velocity were noted between 8 and $15 \mathrm{~h}$ after wounding. The effect of polyclonal antiserum to RHAMM was to abolish the response to wounding. Similar results for inhibition were obtained using anti-fusion protein $\mathrm{Ab}$ (see Table I).

localized increase disappeared by $6 \mathrm{~h}$ after injury (Fig. $5 \mathrm{~b}$ ). There was also a slight increase in the HA staining at $3 \mathrm{~h}$ in control monolayers that had only undergone a change in DM without injury. This increase, however, was over the whole monolayer (data not shown). The reasons for this increase are unclear but could represent a slight injury as a result of the change in medium.

A novel isoform of RHAMM is expressed following injury. Western analyses of control BASMC revealed one protein band of molecular mass $65 \mathrm{kD}$ (Fig. $6 a$ ). The molecular mass of this protein is higher than that previously observed for fibroblasts ( $58 \mathrm{kD}$, references 23,27$) .1 \mathrm{~h}$ after injury, an additional band of $70 \mathrm{kD}$ was noted (Fig. $6 a$ ). Densitometric analysis of the immunoblot showed two slight increases in the expression of this RHAMM protein species after wounding, at 1 and $18 \mathrm{~h}$ (Fig. $6 b$ ). The $65-\mathrm{kD}$ protein was also slightly increased after

Table I. Inhibition of Smooth Muscle Cell Motility by Antibody to RHAMM Fusion Protein

$\begin{array}{lll}\text { Normal IgG }(30 \mu \mathrm{g} / \mathrm{ml}) & \text { Anti-FP Ab }(30 \mu \mathrm{g} / \mathrm{ml}) & \text { Student's } t \text {-test } \\ 8.78 \pm 0.67 \mu \mathrm{m} / \mathrm{h} & 5.62 \pm 0.98 \mu \mathrm{m} / \mathrm{h} & P<0.01\end{array}$

The velocity of smooth muscle cells at the wound edge was measured one hour after injury in the presence of normal IgG or antibody to RHAMM fusion protein (Anti-FP $A b$ ). Anti-FP AB inhibited the increase in velocity noted $1 \mathrm{~h}$ after injury in a similar manner to Antipeptide ${ }^{\text {aa268-288 }}$ Ab (Fig. 3). 


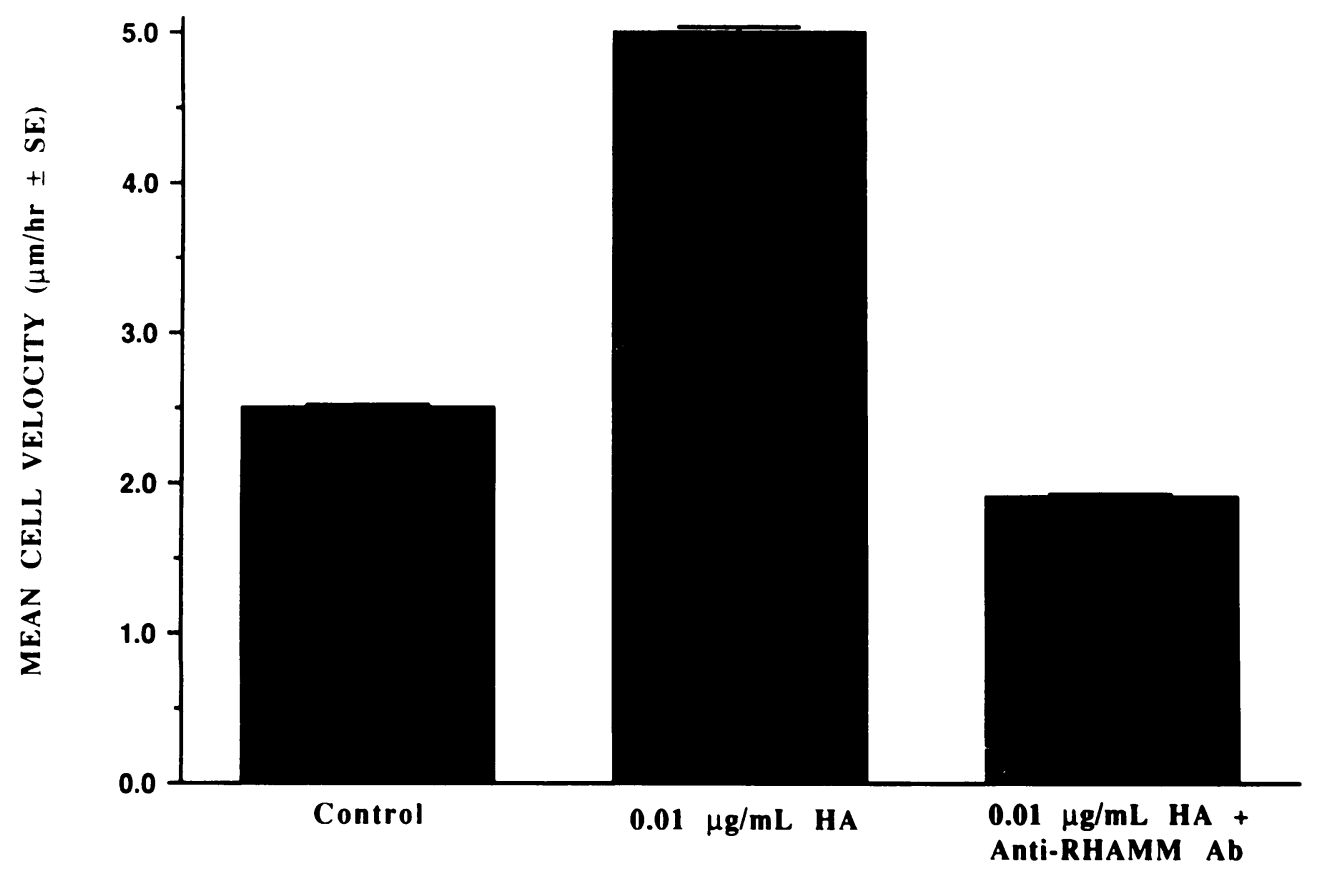

Figure 4. HA stimulation of the random locomotion of BASMC. The random locomotion of subconfluent smooth muscle cells maintained in DM was measured by time-lapse cinemicrography. Following a baseline period of 4 h. in the absence of HA, $0.01 \mu \mathrm{g} /$ $\mathrm{ml} \mathrm{HA}$ was added and the cells were analyzed for a further $4 \mathrm{~h}$. In a different set of monolayers, antiRHAMM peptide aa26x-28x Ab ( $1: 300$ dilution ) was added to the medium prior to the addition of $0.01 \mu \mathrm{g} / \mathrm{ml} \mathrm{HA}$ and the mean cell velocity of the cells was measured for $4 \mathrm{~h}$. The addition of $\mathrm{HA}$ resulted in a significant increase in the random locomotion of BASMC, while polyclonal antiserum to RHAMM completely abolished this stimulatory effect. Similar results for inhibition were obtained using anti-fusion protein Ab (data not shown). injury and remained elevated up to $18 \mathrm{~h}$ (Fig. $6 \mathrm{~b}$ ). The significance of these isoforms are to date unknown. Equal total protein loading of the gel was confirmed by Coomassie blue staining (Fig. $6 c$ ).

Northern analysis of uninjured monolayers revealed the constitutive expression of a $4.1-\mathrm{kb}$ RHAMM mRNA transcript (Fig. 7 A). Quantitative PCR for RHAMM using primers derived from RHAMM isoform II (Entwistle, J., S. Zhang, B. Yang, C. Wong, C. L. Hall, G. Curpen, M. Mowat, A. H. Greenberg, and E. A. Turley, manuscript submitted for publication), that are common to all isoforms, also showed a small increase in RHAMM mRNA from 6-18 h after wounding (Fig. $7 \mathrm{~B}$ ), which differs slightly from the protein data in which an increase was detected by $1 \mathrm{~h}$ after wounding. It is likely that our choice of primers and the high endogenous RHAMM levels were not optimal in allowing us to reverse transcribe and amplify the RHAMM isoforms that are newly synthesized after wounding. Use of other primers derived from the murine cDNA for RHAMM were unsuccessful in RT-PCR suggesting that homology between murine and bovine RHAMM is not high. In any event, these results serve to confirm our protein data that RHAMM increases threefold after injury. We are currently isolating a bovine RHAMM cDNA in order to molecularly characterize specific RHAMM isoforms generated after injury.

Coamplification of an equal amount of $\beta$-actin message from each of the timepoints analyzed confirmed equal loading of RNA and the quantitative validity of the PCR reaction (Fig. $7 \mathrm{~B}$ ). Since equal total protein and RNA was analyzed at each time point, the data for RHAMM protein and mRNA expression presented here represents data normalized for any changes in cell number that may have occurred in the monolayers over time.

Expression of RHAMM at the cell membrane following injury. The most profound change in RHAMM following injury was an alteration in distribution so that RHAMM was expressed on the surface of cells at the leading edge of the wound. These changes were initially followed using confocal microscopy. No background staining was observed when normal $\operatorname{IgG}$ that was preadsorbed to bovine white blood cells was used as a control (Fig. 8 a). Constitutive expression of RHAMM occurred in confluent monolayers of unwounded BASMC maintained in DM (Fig. $8 b$ ), confirming the high RHAMM protein levels observed by western blot and Northern analysis (Figs. $6 a$ and $7 A$ ). As early as $1 \mathrm{~h}$ after injury, RHAMM was redistributed to the cell periphery in cells at the wound edge (Fig. $8 \mathrm{c}$ ), coinciding with the appearance of a $70-\mathrm{kD}$ protein observed in western analysis (Fig. 6 ( ) , and with the increased rates of motility (Fig. 3). This peripheral localization of RHAMM had entirely disappeared by $18 \mathrm{~h}$ and only nuclear staining for the receptor was seen (Fig. $8 d$ ). Staining was specific since it disappeared when the antibody was blocked with excess GSTRHAMM fusion protein (data not shown).

To confirm whether the RHAMM that appeared at the cell periphery was indeed expressed at the cell surface, flow cytometry studies were conducted using anti-peptide ${ }^{\mathrm{a}: 268-28 x} \mathrm{Ab}$. Results showed a significant increase $(P<0.0001$, Student's $t$ test) in surface expression of RHAMM that was maximal $1 \mathrm{~h}$ after injury (Fig. $9 a$ ). Further, these data indicated that $\sim 25 \%$ of the cells were affected by the wounding stimulus (Fig. $9 b$ ) as predicted by the immunofluorescent analysis of fixed monolayers. Indeed, live cell-immunofluorescence studies confirmed this surface localization of RHAMM after wounding of monolayers and demonstrated that increased surface expression of this receptor was localized to cells at the wound edge (Fig. 10), thus accounting for the small changes observed with FACS ${ }^{\circledR}$, protein and mRNA analysis of the entire cell monolayer.

\section{Discussion}

In this study, we demonstrate that the migration of bovine aortic smooth muscle cells following wounding of monolayers requires the participation of the glycosaminoglycan hyaluronan 

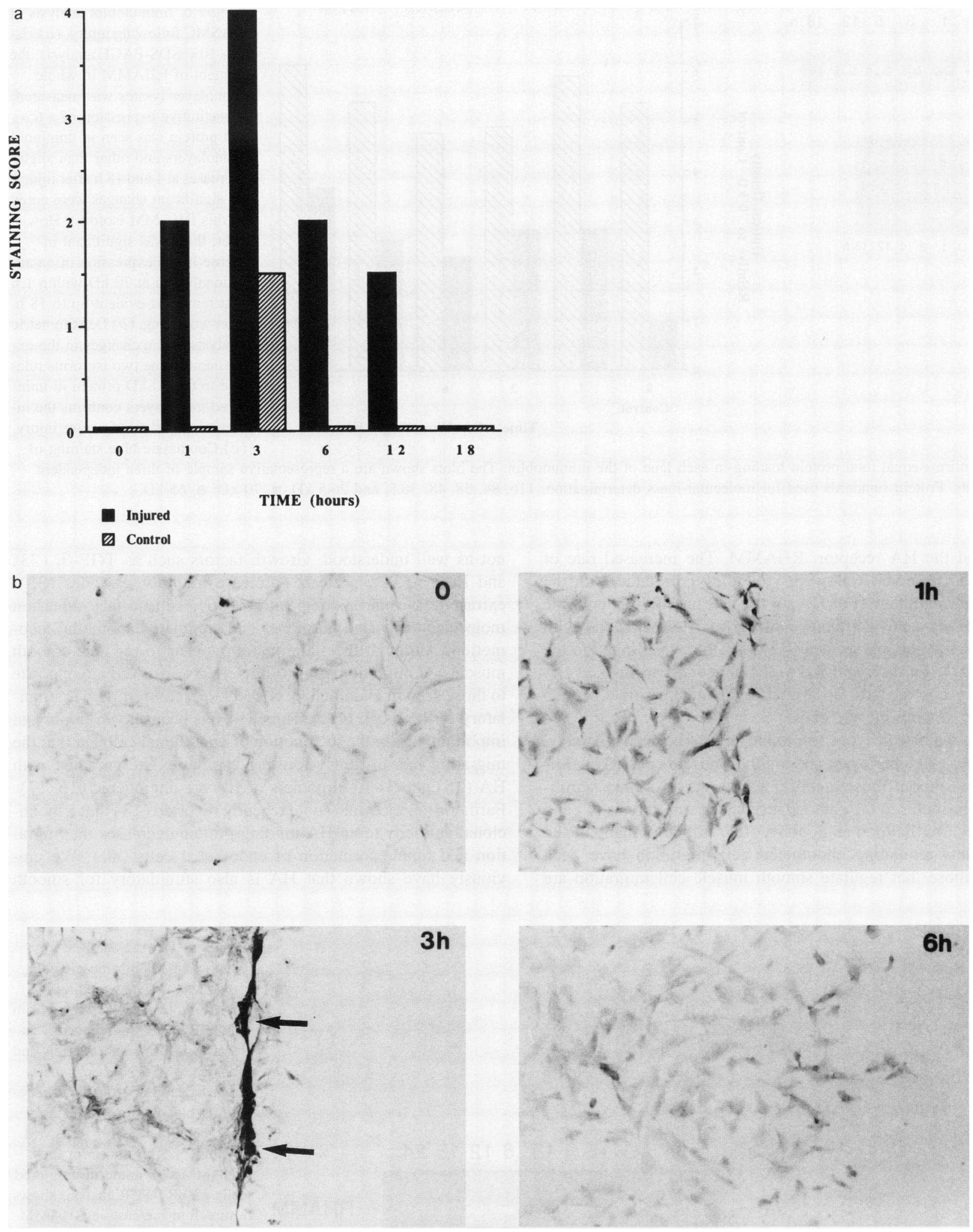

Figure 5. HA association with BASMC monolayers following injury was measured using the biotinylated HA-binding region of aggrecan isolated from bovine nasal cartilage as a probe for cell-associated HA that was subsequently localized using an avidin-biotin-peroxidase conjugate and diaminobenzadine as the color product. (a) Staining for HA on BASMC monolayers was scored semiquantitatively from 0 to 4 by a blinded observer. Cell associated HA increased to a maximum at $3 \mathrm{~h}$ after injury. Thereafter, the staining decreased and was absent again by $18 \mathrm{~h}$ after injury. (b) The increased staining observed at $3 \mathrm{~h}$ after wounding was primarily localized to the wound edge (arrows). Control monolayers in which the medium was changed without injury showed only a slight increase in staining for HA. In addition, this increase was generalized over the whole monolayer and may represent a slight injury as a result of change of medium. The data shown are a representative sample of three independent experiments. 

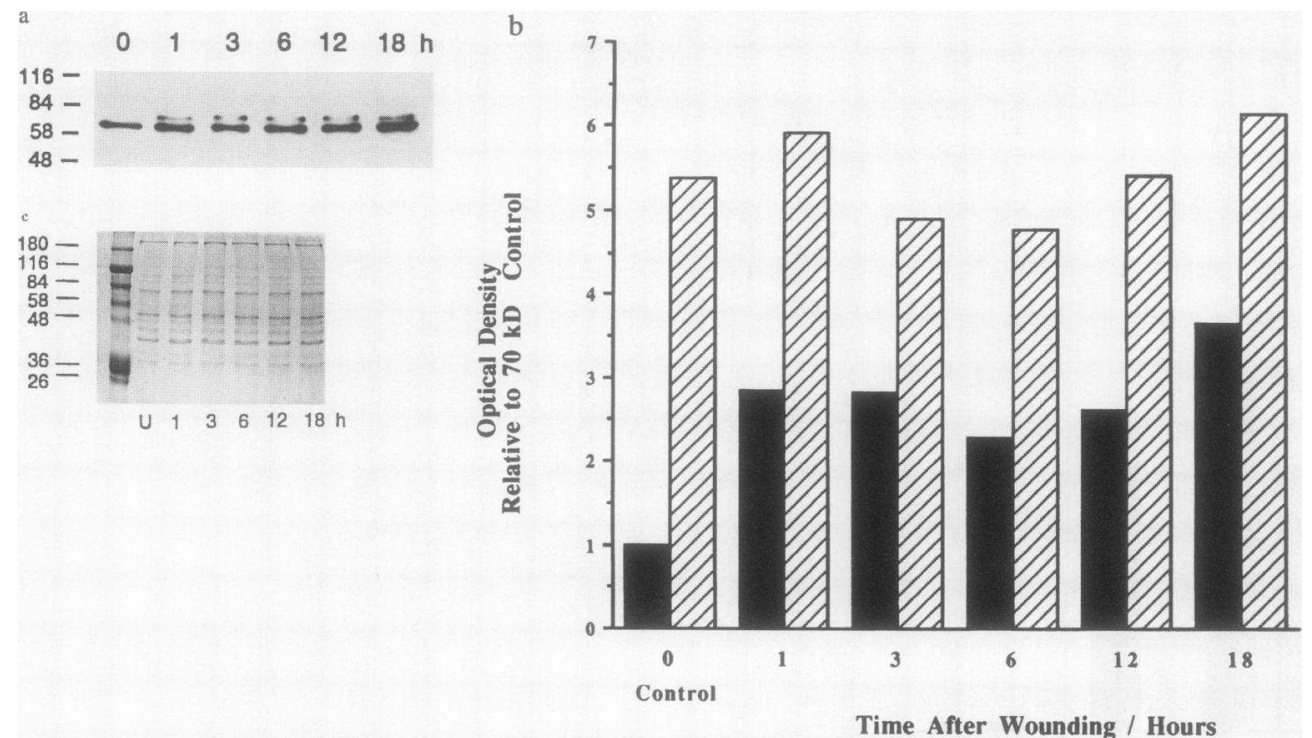

Figure 6. Immunoblot analysis of BASMC following injury. (a) Using $10 \%$ SDS-PAGE analysis, the content of RHAMM in whole monolayer lysates was measured. Constitutive expression of a 65$\mathrm{kD}$ protein was seen in uninjured monolayers and other than slight increases at 1 and $18 \mathrm{~h}$ after injury, no significant changes were noted in this RHAMM isoform. However, there was significant increase in the expression of an additional band at $70 \mathrm{kD}$ within $1 \mathrm{~h}$ that remained evident up to $18 \mathrm{~h}$ after wounding. ( $b$ ) Densitometric analysis of the changes in the expression of the two isoforms relative to the $70-\mathrm{kD}$ protein in uninjured monolayers confirms the increase in this protein after injury. (c) Coomassie blue staining of

the gel confirms equal total protein loading in each lane of the immunoblot. The blots shown are a representative sample of three independent experiments. Protein standards used for molecular mass determination: 116, 84, 58, 48, 36.5, and $26.5 \mathrm{kD}$. m, $70 \mathrm{kD}$; $\mathbf{\square}, 65 \mathrm{kD}$.

(HA) and the HA receptor, RHAMM. The increased rate of locomotion observed following wounding correlated with the increased accumulation of HA on the cell monolayer, with the expression of a novel protein isoform of RHAMM, and with the appearance of cell surface RHAMM that was limited to the wound edge. Further, anti-RHAMM antisera that blocked HA binding to this receptor abolished repair of the single scratch wound by smooth muscle cells.

Three major cell types are found in arterial walls, namely, endothelial cells, pericytes and smooth muscle cells (32). Migration of smooth muscle cells into the vessel intima significantly contributes to the pathogenesis of atherosclerosis (1) and restenosis after balloon angioplasty (2). Although many of the mechanisms regulating endothelial cell migration have been defined, those that regulate smooth muscle cell migration are not as well understood. Growth factors such as TGF- $\beta_{1}(33)$ and PDGF (34), protease-protease inhibitor cascades (35), extracellular matrix composition (36), cell surface adhesion molecules (37), and hormones (38) regulate endothelial locomotion. Although the same factors appear to regulate smooth muscle cell migration, most of the effects observed are opposite to those seen in endothelial cells (39). In contrast, HA is stimulatory for both cell types. Thus, HA has been shown to play an important part in the locomotion of endothelial cells, in that the migrating tips of newly-forming capillaries are enriched with HA (15) and 3-16 oligomers of HA are angiogenic $(16,17)$. Further, Banerjee and Toole recently reported (18) that a monoclonal antibody to an HA-binding protein decreases the migration and tubule formation of endothelial cells (40). We previously have shown that HA is also stimulatory for smooth

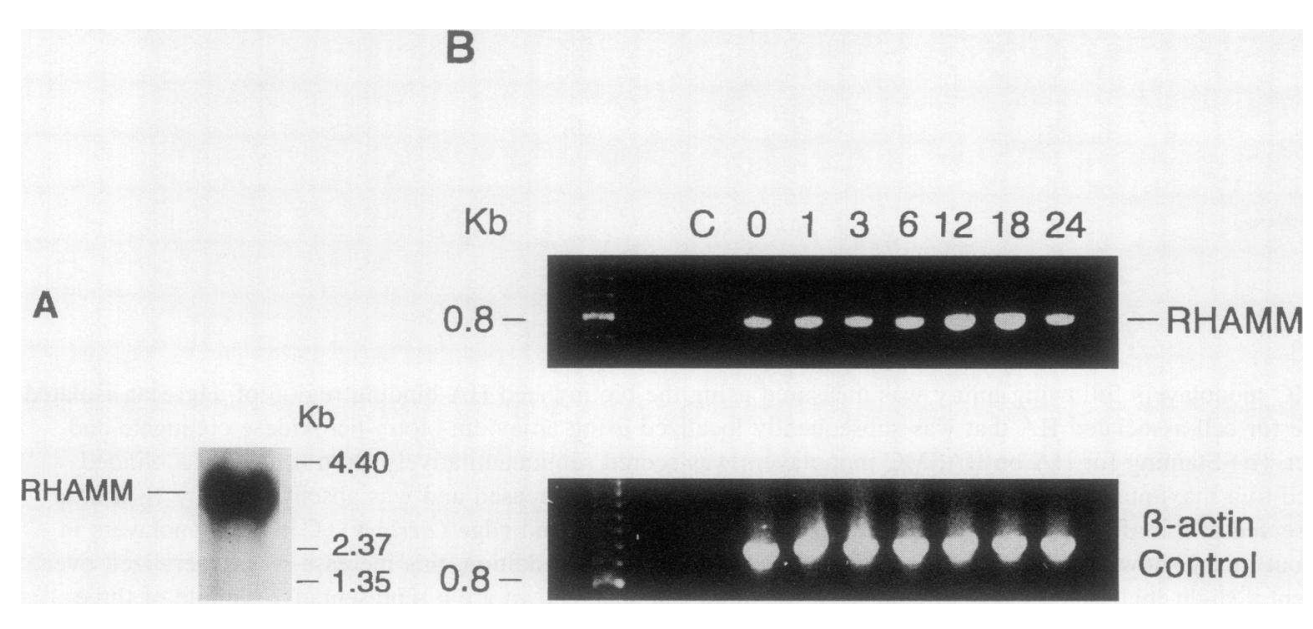

Figure 7. RHAMM mRNA changes in smooth muscle cell monolayers after wounding. $(A)$ $80 \mu \mathrm{g}$ of total RNA extracted from whole BASMC monolayers was separated on $1 \%$ agarose gels and transferred to a Nytran ${ }^{\mathrm{TM}}$ membrane by capillary transfer. The resulting blot was probed using a ${ }^{32}$ P-labeled cDNA for RHAMM. A single 4.1-kb transcript for RHAMM was noted in uninjured cells. $(B)$ RT-PCR analysis shows a threefold increase in RHAMM mRNA between 6 and $18 \mathrm{~h}$ after injury. Coamplification of $\beta$-actin transcripts demonstrates equal amplification of all samples confirming the quantitative nature of the analysis. $C$ represents a control lane of RNA treated with RNAase before amplification. 


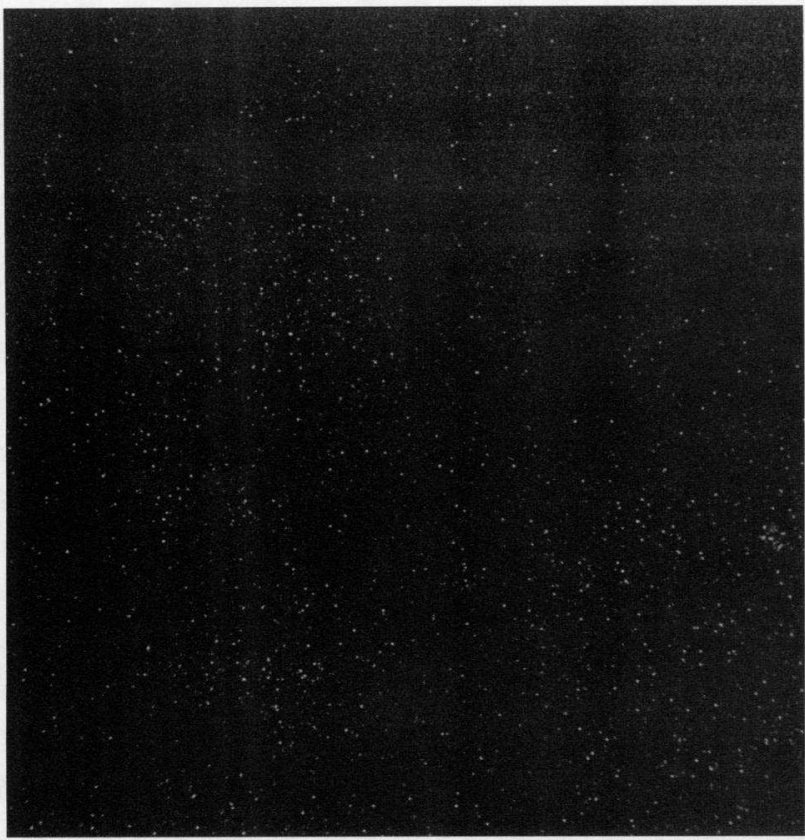

C

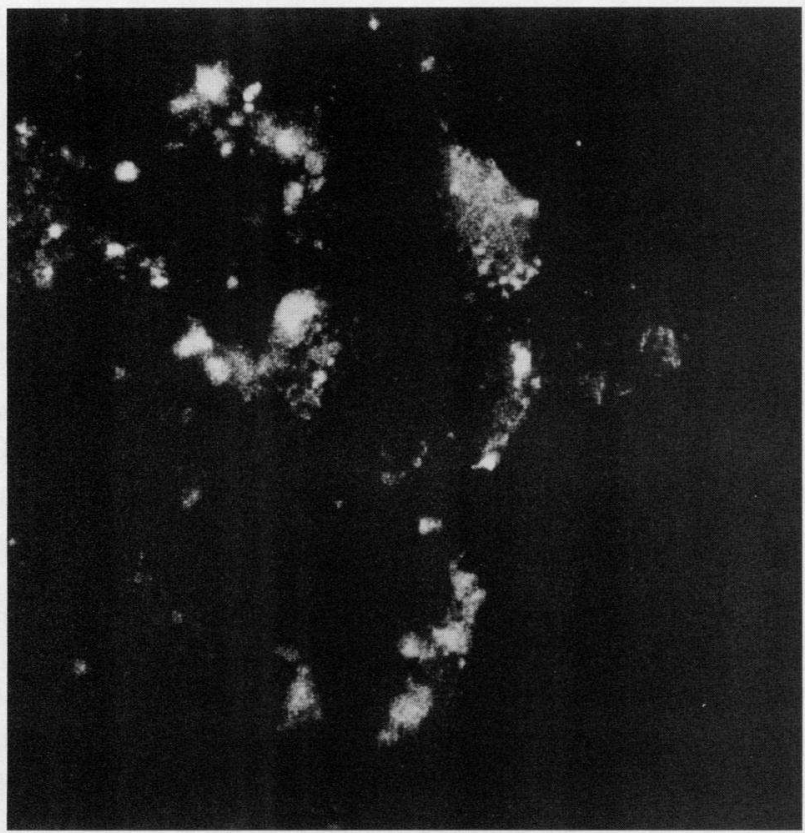

b

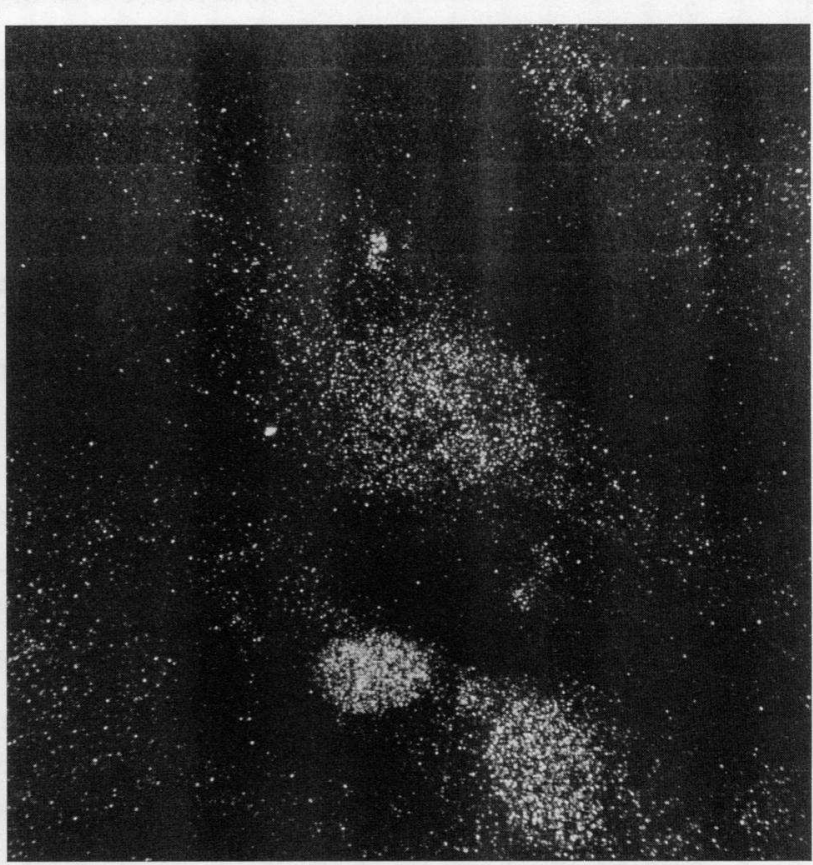

d

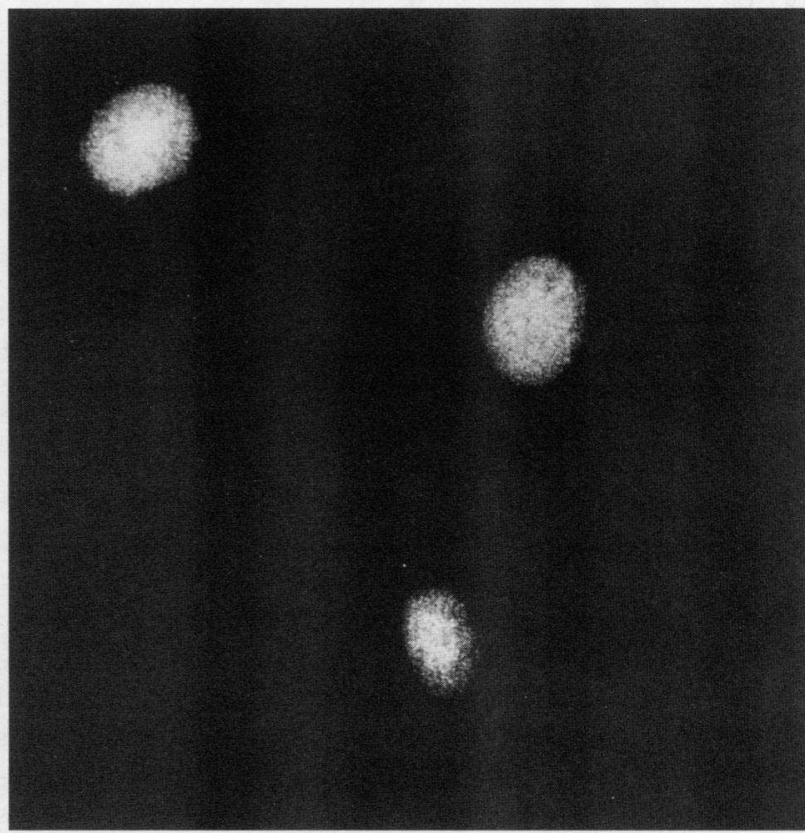

Figure 8. Distribution of RHAMM in BASMC monolayers following wounding injury. Using anti-peptide ${ }^{\text {an268-288 }}$ Ab, the distribution of RHAMM was studied in uninjured monolayers and $1,3,6,12$, and $18 \mathrm{~h}$ after injury confocal scanning laser microscopy. (a) Normal IgG, preadsorbed to bovine white blood cells, was used as a control and did not show significant staining. (b) Constitutive expression of RHAMM was noted in uninjured BASMC. (c) As early as $1 \mathrm{~h}$ after injury, there was an increase in staining for the protein at the cell periphery in cells at the leading edge of the wound. $(d)$ By $18 \mathrm{~h}$, when the rate of locomotion had decreased, no staining was observed at the periphery of the cell and predominantly nuclear staining was observed. These changes were not observed in control monolayers (data not shown).

muscle cell migration (19). In the present study, the increase in cell-associated HA coincided with both the acceleration in smooth muscle cell locomotion and surface localization of RHAMM observed after wounding. The finding of increased HA following single scratch wounding of smooth muscle cell monolayers is consistent both with the observation of other investigators that HA synthesis is up-regulated following other types of tissue injury $(14,41,42)$, and with the proposal that HA regulates locomotion in an autocrine manner as previously identified in fibroblasts $(11,27)$.

It is now established that HA, like other components of the extracellular matrix, affects cell behavior, at least in part by 
a

On.

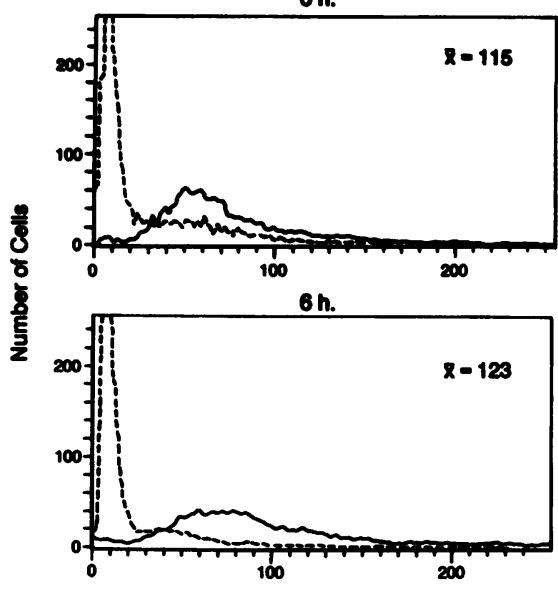

$1 \mathrm{~h}$.

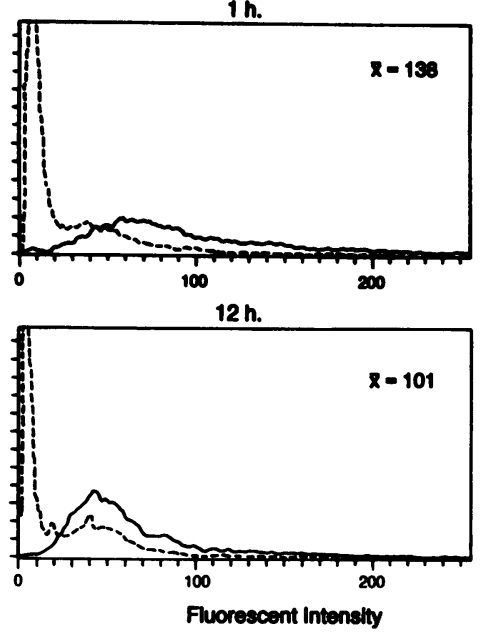

$3 \mathbf{h}$

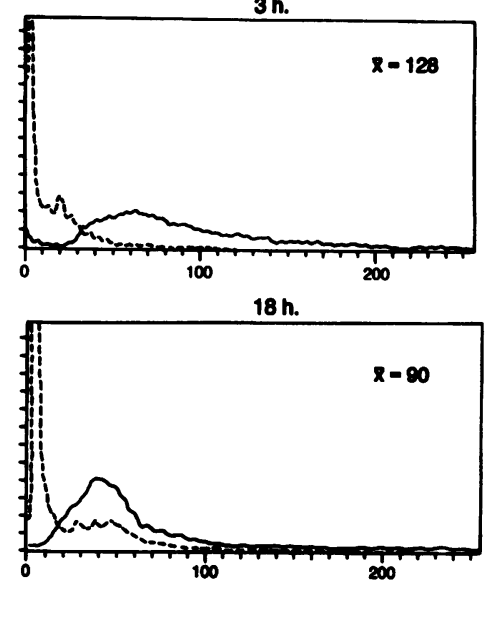

b

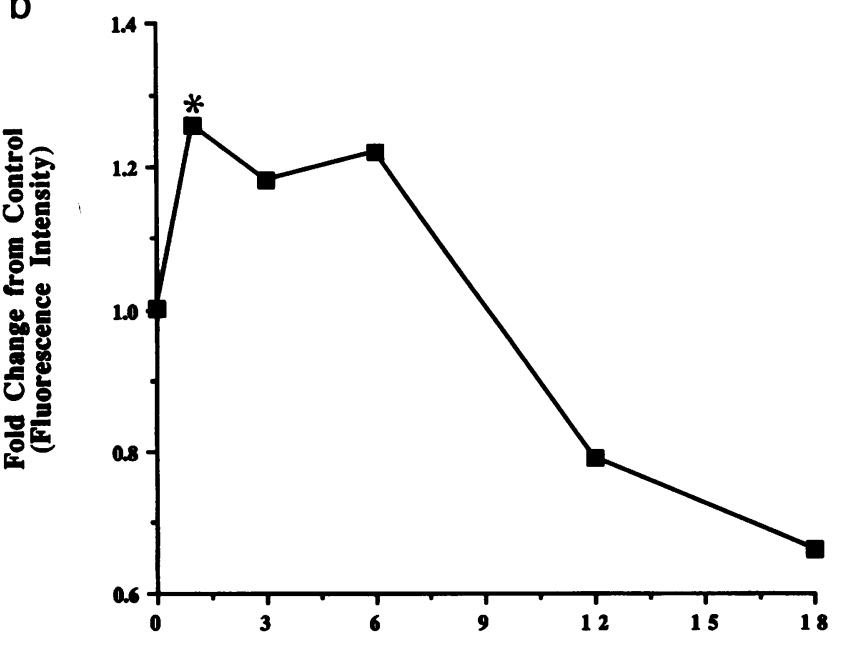

Time/Hours

Figure 9. Flow cytometric analysis for surface localization of RHAMM following wounding. ( $a$ ) Control and injured monolayers were harvested following injury and stained for FACS ${ }^{\circledR}$ using either anti-peptide ${ }^{\text {aa268-288 }}$ $\mathrm{Ab}$ (solid line) or normal IgG (dashed line). Significant increase in cell surface expression of RHAMM occurred maximally $1 \mathrm{~h}$ after injury $(* P$ $<0.0001$, Student's $t$-test). (b) Analysis of the FACS ${ }^{\circledR}$ data as described in Methods reveals that increased cell surface expression of RHAMM occurs in $\sim 25 \%$ of the cell population following injury.

interaction with cell-associated receptors $(10,21)$. Two receptors have been molecularly characterized so far and include CD44 (22) and RHAMM (23). RHAMM has been implicated in the HA-regulated locomotion of ras-transformed fibroblasts (11) and their response to TGF- $\beta_{1}$ (27), astrocytes (43), neuronal extension (44), as well as in macrophage chemotaxis (Savani, R. C., P. Liu, C. Wang, F. E. Simons, C. Kaplan, R. Overhiser, R. L. Panek, R. Stern, and E. A. Turley, manuscript in preparation). CD44 has been implicated in the locomotion of melanoma cells (45), fibroblasts (46), and astrocytes (47). However, the role of these HA receptors in smooth muscle cell locomotion has not previously been defined. Inhibition of wound repair by antisera monospecific for RHAMM confirmed the critical role for this receptor in mediating this process. Recently, RHAMM has been shown to regulate growth as well as migration (Yang, B., X. Yang, S. Zhang, M. Turley, S. Samuel, R. C. Savani, A. H. Greenberg, and E. A. Turley, manuscript submitted for publication). Therefore, anti-RHAMM antisera may have affected both these properties. We have conclusively shown that this inhibition of wound repair is at least in part due to the inhibition of motility (see Fig. 3). Moreover, these data

provide further evidence of the critical role of RHAMM/HA interactions in this process since these antisera also blocked binding of HA to RHAMM.

Although the onset of migration one hour after injury correlated with a significant increase in the expression of cell surface RHAMM and with the appearance of a 70-kD RHAMM isoform at the wound edge, levels of RHAMM remained high even when locomotion was declining. However, the immunolocalization data provide strong evidence that links the initial $12 \mathrm{~h}$ of increased motility following injury with the redistribution of RHAMM to the cell surface followed by its disappearance so that, by $18 \mathrm{~h}$, only nuclear staining was observed. We have previously correlated rate of locomotion with cell surface localization of RHAMM in other cell types $(27,43,44)$. The significance of the nuclear staining is unknown, but has previously been noted in fibroblasts (27). Significantly, there was no detectable increase in RHAMM mRNA at one hour and it is possible that the appearance of the higher molecular weight form of RHAMM represents posttranslational modification of the protein that allows cell surface expression. Alternatively, a minor up-regulation of a specific isoform occurred for which we do not have appropriate primers 


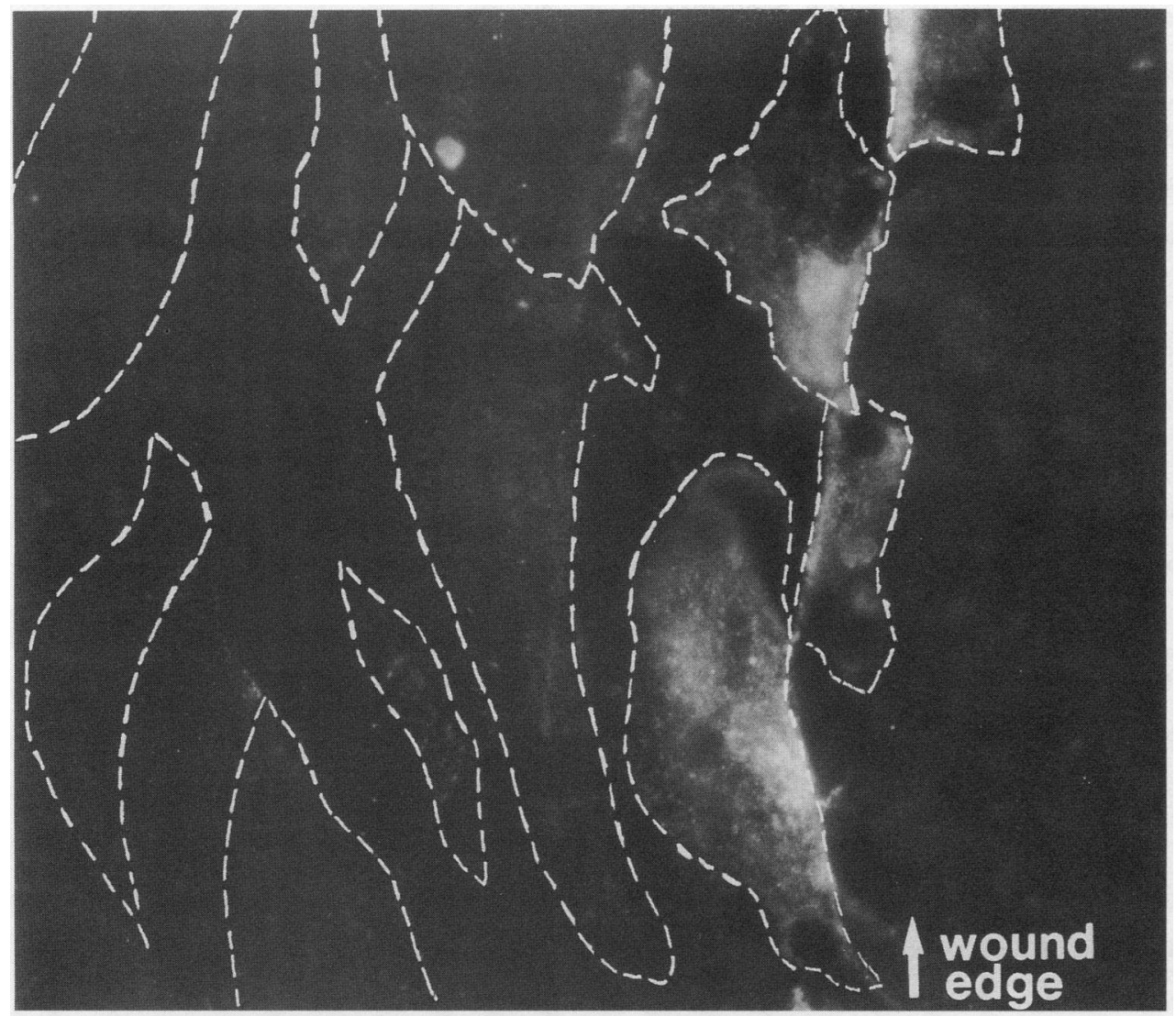

Figure 10. Live cell-immunofluorescence of BASMC monolayers. To observe the cell surface distribution of RHAMM one hour after wounding, monolayers were incubated with antipeptide ${ }^{\text {an268-288 }} \mathrm{Ab}$ (1:50 dilution in DM) for 30 min and subsequently to rhodamine-conjugated goat anti-rabbit ( $1: 50$ dilution in DM) for a further $30 \mathrm{~min}$. The monolayer was then fixed with fresh $3 \%$ paraformaldehyde in PBS and viewed with epifluorescence at $510-560 \mathrm{~nm}$. Staining for RHAMM at the cell surface was restricted to cells at the wound edge. The cell boundaries within the field are represented by the white outline overlaid on the photomicrograph. for RT-PCR. To this end, we are currently sequencing a cDNA obtained from a smooth muscle cell library created from the neointimal layer of carotid arteries injured by balloon catheterization to assess this latter possibility.

The mechanism(s) by which RHAMM associates with the membrane are unknown. We recently cloned the RHAMM gene (Entwistle et al., manuscript submitted for publication) and noted that the three isoforms generated from this gene do not encode a signal sequence or a transmembrane domain. However, membrane-associated RHAMM has been unequivocally demonstrated previously in fibroblasts $(23,48,49)$, and one isoform (RHAMM I-2A) accumulates in the extracellular compartment (Entwistle, J., S. Zhang, B. Yang, C. Wong, C. L. Hall, G. Curpen, M. Mowat, A. H. Greenberg, and E. A. Turley, manuscript submitted for publication). All RHAMM isoforms contain a carboxy terminus similar to Decay Accelerating Factor that is glycolipid modified (50). We are currently investigating whether the $70-\mathrm{kD}$ RHAMM noted here is also modified by glycolipid.

In summary, RHAMM regulates the directional migration of smooth muscle cells following wounding injury and membrane localization of this protein appears to be critical to the process. These findings have implications for the processes involved in the cellular response to injury, and perhaps for the pathogenesis of vascular diseases that involve smooth muscle cell locomotion.

\section{Acknowledgments}

We thank Dr. A. H. Greenberg for critical review of the manuscript. The expert assistance of Dr. E. Rector (Flow Cytometry Laboratory,
Department of Immunology, University of Manitoba, Winnipeg) and Ms. L. Lange is gratefully appreciated.

This research was funded by Hyal Corporation (to E. A. Turley), by grants from the Manitoba Medical Services Foundation and the Manitoba Health Research Council (both to R. C. Savani), and by the National Institutes of Health, grant no. 18645 (T. N. Wight). E. A. Turley is the recipient of a Children's Hospital of Winnipeg Research Foundation Scholarship.

\section{References}

1. Ross, R., and J. A. Glomset. 1976. The pathogenesis of atherosclerosis. New Engl. J. Med. 295:369-377, 420-425.

2. Casscells, W. 1992. Migration of smooth muscle and endothelial cells: critical events in restenosis. Circulation. 86:723-729.

3. Murphy, J. D., M. Rabinovitch, J. D. Goldstein, and L. M. Reid. 1981. The structural basis of persistent pulmonary hypertension of the newborn infant. $J$. Pediatr. 98:962-967.

4. Ross, R. 1993. The pathogenesis of atherosclerosis: a perspective for the 1990s. Nature (Lond.). 362:801-809.

5. Madri, J. A., O. Kocher, J. R. Merwin, L. Bell, and J. Yannariello-Brown. 1989. The interactions of vascular cells with solid phase (matrix) and soluble factors. J. Cardiovasc. Pharmacol. 14:S70-S75.

6. Naito, M., T. Hayashi, M. Kuzuya, C. Funaki, K. Asai, and F. Kuzuya. 1990. Effects of fibrinogen and fibrin on the migration of vascular smooth muscle cells in vitro. Atherosclerosis. 83:9-14.

7. Majack, R. A., and A. W. Clowes. 1984. Inhibition of vascular smooth muscle cell migration by heparin-like glycosaminoglycans. J. Cell. Physiol. 118:253-256.

8. Laurent, T. C., and J. R. E. Fraser. 1992. Hyaluronan. FASEB (Fed. Am. Soc. Exp. Biol.) J. 6:2397-2404.

9. Toole, B. P. 1982. Developmental role of hyaluronate. Connect. Tissue Res. 10:93-100.

10. Turley, E. A. 1992. Hyaluronan and cell locomotion. Cancer Metastasis Rev. 11:21-30

11. Turley, E. A., L. Austen, K. Vandeligt, and C. Clary. 1991. Hyaluronan 
and a cell-associated hyaluronan binding protein regulate the locomotion of rastransformed cells. J. Cell Biol. 112:1041-1047.

12. Nettelbladt, O., J. Bergh, M. Schenholm, A. Tengblad, and R. Hallgren. 1989. Accumulation of hyaluronic acid in the alveolar interstitial tissue in bleomycin-induced alveolitis. Am. Rev. Respir. Dis. 139:759-762.

13. Waldenström, A., H. J. Martinussen, B. Gerdin, and R. Hällgren. 1991. Accumulation of hyaluronan and tissue edema in experimental myocardial infarction. J. Clin. Invest. 88:1622-1628.

14. Weigel, P. H., G. M. Fuller, and R. D. LeBoeuf. 1986. A model for the role of hyaluronic acid and fibrinogen in the early events of inflammatory response and wound healing. J. Theor. Biol. 119:219-234.

15. Ausprunk, D. H., C. L. Boudreau, and D. A. Nelson. 1981. Proteoglycans in the microvasculature II: histochemical localization in proliferating capillaries of the rabbit cornea. Am. J. Pathol. 103:367-375.

16. West, D. C., I. N. Hampson, F. Arnold, and S. Kumar. 1985. Angiogenesis induced by degradation products of hyaluronic acid. Science (Wash. DC). 228:1324-1326.

17. West, D. C., and S. Kumar. 1989. The effect of hyaluronate and its oligosaccharides on endothelial cell proliferation and monolayer integrity. Exp. Cell Res. 183:179-196.

18. Banerjee, S. D., and B. P. Toole. 1992. Hyaluronan-binding protein in endothelial cell morphogenesis. J. Cell Biol. 119:643-652.

19. Boudreau, N., and M. Rabinovitch. 1991. Developmentally regulated changes in extracellular matrix in endothelial and smooth muscle cells in the ductus arteriosus may be related to intimal proliferation. Lab. Invest. 64:187199.

20. Turley, E. A., and N. Auersperg. 1989. A hyaluronate binding protein transiently codistributes with $\mathrm{p} 21^{\mathrm{k} \text {-ras }}$ in cultured cell lines. Exp. Cell Res. 182:340-348.

21. Toole, B. P. 1990. Hyaluronan and its binding proteins, the hyaladherins. Curr. Opin. Cell Biol. 2:839-844.

22. Haynes, B. F., H.-X. Liao, and K. L. Patton. 1991. The transmembrane hyaluronate receptor (CD44): multiple functions, multiple forms. Cancer Cells (Cold Spring, Harbor). 3:347-350.

23. Hardwick, C., K. Hoare, R. Owens, H. P. Hohn, M. Hook, D. Moore, V. Cripps, L. Austen, D. M. Nance, and E. A. Turley. 1992. Molecular cloning of a novel hyaluronan receptor that mediates tumor cell motility. J. Cell. Biol. 117:1343-1350.

24. Turley, E. A. 1982. Purification of a hyaluronate-binding protein fraction that modifies cell social behaviour. Biochem. Biophys. Res. Commun. 108:10161024.

25. Turley, E. A., D. Moore, and L. J. Hayden. 1987. Characterization of hyaluronate binding proteins isolated from 3T3 and murine sarcoma virus transformed 3T3 cells. Biochemistry. 26:2997-3005.

26. Boudreau, N., E. A. Turley, and M. Rabinovitch. 1991. Fibronectin, hyaluronan, and a hyaluronan binding protein contribute to increased ductus arteriosus smooth muscle cell migration. Dev. Biol. 143:235-247.

27. Samuel, S. K., R. A. R. Hurta, M. A. Spearman, J. A. Wright, E. A Turley, and A. H. Greenberg. 1993. TGF- $\beta_{1}$ stimulation of cell locomotion is mediated by the hyaluronan receptor RHAMM and hyaluronan. J. Cell Biol. 123:749-758

28. Yang, B., L. Zhang, and E. A. Turley. 1993. Identification of two hyaluronan-binding domains in the hyaluronan receptor RHAMM. J. Biol. Chem 268:8617-8623.

29. Hoare, K., R. C. Savani, C. Wang, B. Yang, and E. A. Turley. 1993. Identification of hyaluronan binding proteins using a biotinylated hyaluronan probe. Connect. Tissue Res. 30:117-126.
30. Ripellino, J. A., M. M. Killinger, R. U. Margolis, and R. K. Margolis. 1985. The hyaluroninc acid binding region as a specific probe for the localization of hyaluronic acid in tissue sections. J. Histochem. Cytochem. 33:1066-1086.

31. Chomczynski, P., and N. Sacchi. 1987. Single-step method of RNA isolation by acid guanidinium thiocyanate-phenol-chloroform extraction. Anal. Biochem. 162:156-159.

32. Fishman, A. P. 1982. Endothelium. Annu. NY Acad. Sci. 401:1-270.

33. Madri, J. A., O. Kocher, J. R. Merwin, L. Bell, A. Tucker, and C. T Basson. 1990. Interactions of vascular cells with Transforming Growth Factor- $\beta$ Annu. NY Acad. Sci. 593:243-258.

34. Ross, R., E. W. Raines, and D. F. Bowen-Pope. 1986. The biology of platlet-derived growth factor. Cell. 46:155-169.

35. Moscatelli, D., and D. B. Rifkin. 1988. Membrane and matrix localization of proteinases: a common theme in tumor cell invasion and angiogenesis. Biochim. Biophys. Acta. 948:67-85.

36. Madri, J. A., and M. D. Basson. 1992. Extracellular matrix-cell interactions: dynamic modulators of cell, tissue and organism structure and function. Lab. Invest. 66:519-521.

37. Basson, C. T., W. J. Knowles, L. Bell, S. M. Albelda, V. Castronovo, L. A. Liotta, and J. A. Madri. 1990. Spatiotemporal segregation of endothelial cell integrin and nonintegrin extracellular matrix-binding proteins during adhesion events. J. Cell Biol. 110:789-801.

38. Bell, L., and J. A. Madri. 1990. Influence of the Angiotensin system on endothelial and smooth muscle cell migration. Am. J. Pathol. 137:7-12.

39. Bell, L., and J. A. Madri. 1989. Effect of platelet factors on migration of cultured bovine aortic endothelial and smooth muscle cells. Circ. Res. 65:10571065.

40. Banerjee, S. D., and B. P. Toole. 1991. Monoclonal antibody to chick embryo hyaluronan-binding protein: changes in distribution of binding protein during early brain development. Dev. Biol. 146:186-197.

41. Bray, B. A., P. M. Sampson, M. Osman, A. Giandomenico, and G. M Turino. 1991. Early changes in lung tissue hyaluronan (hyaluronic acid) and hyaluronidase in bleomycin-induced alveolitis in hamsters. Am. Rev. Respir. Dis. 143:284-288.

42. Hällgren, R., T. Samuelsson, T. C. Laurent, and J. Modig. 1989. Accumulation of hyaluronan (hyaluronic acid) in the lung in adult respiratory distress syndrome. Am. Rev. Respir. Dis. 139:682-687.

43. Turley, E. A., M. Z. Hossain, T. Sorokan, L. M. Jordan, and J. I. Nagy. 1994. Astrocyte and microglial motility in vitro is functionally dependent on the hyaluronan receptor RHAMM. Glia, In press.

44. Nagy, J. I., J. Hacking, U. N. Frankenstein, and E. A. Turley. 1994. Requirement of the hyaluronan receptor RHAMM in neurite extension and motility as demonstrated in primary neurons and neuronal cell lines. J. Neurosci. In press.

45. Thomas, L., H. R. Byers, J. Vink, and I. Stamenkovic. 1992. CD44H regulates tumor cell migration on a hyaluronate-coated substrate. J. Cell Biol. 118:971-977.

46. Messadi, D. V., and C. N. Bertolami. 1993. CD44 and hyaluronan expression in human cutaneous scar fibroblasts. Am. J. Pathol. 142:1041-1049.

47. Asher, R., and A. Bignami. 1992. Hyaluronate binding and CD44 expression in human glioblastoma cells and astrocytes. Exp. Cell Res. 203:80-90.

48. Turley, E. A. 1989. The role of a cell-associated hyaluronan-binding protein in fibroblast behaviour. CIBA Found. Symp. 143:121-137.

49. Klewes, L., E. A. Turley, and P. Prehm. 1993. The hyaluronate synthase from a eukaryotic cell line. Biochem. J. 290:791-795.

50. Nicholson-Weller, A., and C. E. Wang. 1994. Structure and function of DAF (CD55). J. Lab. Clin. Med. 123:485-491. 